\title{
Early Childhood Caries Is Associated with Genetic Variants in Enamel Formation and Immune Response Genes
}

\author{
Zerrin Abbasoğlu ${ }^{a}$ illknur Tanboğa ${ }^{a} \quad$ Erika Calvano Küchler ${ }^{d}$ Kathleen Deeley ${ }^{d}$ \\ Megan Weber ${ }^{d}$ Cigdem Kaspar $^{b}$ May Korachic ${ }^{c}$ Alexandre R. Vieira ${ }^{d-f}$ \\ ${ }^{a}$ Department of Pediatric Dentistry, Faculty of Dentistry, Marmara University, and Departments of ${ }^{b}$ Biostatistics and \\ ${ }^{\mathrm{C}}$ Genetics and Bio-Engineering, Yeditepe University, Istanbul, Turkey; ${ }^{\mathrm{d}}$ Department of Oral Biology and Center for

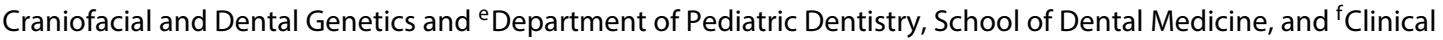 \\ and Translational Science Institute, University of Pittsburgh, Pittsburgh, Pa., USA
}

\section{Key Words}

Early childhood caries - Gene-environment interaction .

Risk and protective factors

\begin{abstract}
Early childhood caries (ECC) is a chronic, infectious disease that affects the primary dentition of young children. It is the result of an imbalance of risk factors and protective factors that influence the disease. The aim of this study was to assess genetic and environmental factors that may contribute to ECC. Two hundred and fifty-nine unrelated children were evaluated using a cross-sectional design. Data on oral habits were obtained through a questionnaire, and caries experience data were collected by clinical examination. Twentythree markers in 10 genes were studied. Genotyping of the selected polymorphisms was carried out by real-time PCR. Regression analyses were performed comparing individuals with and without caries experience. Of 259 subjects, 123 were caries free. The genotype TT in ALOX15 (rs7217186) was a risk factor for ECC, whereas the genotypes GG in ENAM (rs1264848), AG and GG in KLK4 (rs198968), CT in LTF
\end{abstract}

(rs4547741), and GG in TUFT1 (rs3790506) were protective for EEC. In conclusion, environmental factors and gene interactions can act as protective or risk factors for ECC. These factors together contribute to the presence and severity of the disease.

(c) 2014 S. Karger AG, Basel

Early childhood caries (ECC) is defined as 'the presence of one or more decayed (noncavitated or cavitated lesions), missing (due to caries), or filled tooth surfaces' in any primary tooth in a 71-month or younger child [Drury et al., 1999]. ECC represents one of the major diseases that impact on children's health and remains a public health problem in many communities. It results from a chronic imbalance between multiple risk factors and protective factors [American Academy of Pediatric Dentistry, 2008].

It is well established that environmental factors such as diet, oral hygiene, other oral habits, and socioeconomic factors are risk or protective factors for caries [Levy et al., 2003; Ferreira et al., 2007; Menghini et al., 2008; Tan-

\section{KARGER 125}

(C) 2014 S. Karger AG, Basel

0008-6568/14/0491-0070\$39.50/0

E-Mail karger@karger.com

www.karger.com/cre
Alexandre R. Vieira, DDS, MS, PhD

Department of Oral Biology, 614 Salk Hall

School of Dental Medicine, University of Pittsburgh

3501 Terrace Street, Pittsburgh, PA 15261 (USA)

E-Mail arv11@pitt.edu 
nure et al., 2012c]. However, the factors related to the host are genetically controlled, and environmental factors can overcome the genetic component of this complex disease. Our more recent studies continue to demonstrate that genetic variation in the host is associated with caries experience, and these variations can play a role in caries etiology as risk factors or as protective factors [Patir et al., 2008; Deeley et al., 2008; Vieira et al., 2008; Ozturk et al., 2010; Shaffer et al., 2011; Tannure et al., 2012a, b; Shimizu et al., 2012; Wang et al., 2012; Briseño-Ruiz et al., 2013; Shimizu et al., 2013]. However, one criticism regarding these studies is the incomplete information concerning environmental factors to be included as covariates in the genetics analysis. In this study, we evaluated the association between genes involved in enamel formation and genes involved in immune response and their interaction with environmental factors in ECC experience.

\section{Subjects and Methods}

The Human Ethics Committee of Marmara University, Turkey, 2011, and the University of Pittsburgh Institutional Review Board approved this study. Informed consent was obtained from all parents/legal guardians.

Healthy unrelated children with no chronic illnesses from 2 to 5 years of age who had no systemic fluoride consumption were enrolled in this cross-sectional study. All children sought dental treatment at the Pediatric Dental Clinics of Marmara University from 2011 to 2012, and all parents/caregivers answered a questionnaire about the children's diet and oral hygiene habits.

\section{Determination of Caries Experience}

The examiner (Z.A.) carried out the clinical examination after being trained by an experienced specialist (M.K.) in pediatric dentistry. Caries was diagnosed by visual examination and was recorded if there was definite visual evidence of a breach in the enamel with or without extension into dentin. Visible presence of white spot lesions due to enamel demineralization was also recorded. Subjects were seated in a dental chair, and the examiner used a probe and dental mirror according to the criteria recommended by the World Health Organization's guidelines. Caries experience was assessed using the $\mathrm{dmft}$ and $\mathrm{dmfs}$ indexes for each individual. Calculations excluded teeth lost to trauma or primary teeth lost to exfoliation.

Subjects were classified according to caries experience level. They were categorized into two groups: caries free (children with $\mathrm{dmft}=0)$ and children with caries experience $(\mathrm{dmft} \geq 1)$.

\section{DNA Samples and Genotyping}

Genomic DNA was extracted from buccal cells using a QIAmp DNA isolation protocol. Twenty-four markers in 10 genes (7 involved in enamel formation and 3 involved in immune response) were included in this study (table 1). Genotyping was performed by PCRs using the TaqMan method [Ranade et al., 2001] with an ABI PRISM ${ }^{\circledR} 7900$ HT Sequence Detection System (Foster City,
Table 1. Genes and markers included in this study

\begin{tabular}{|c|c|c|c|c|}
\hline $\begin{array}{l}\text { Genetic } \\
\text { marker }\end{array}$ & Gene & Chromosome & $\begin{array}{l}\text { Base } \\
\text { change }\end{array}$ & $\begin{array}{l}\text { Minor allele } \\
\text { frequency }\end{array}$ \\
\hline rs2619112 & ALOX 15 & 17 & $\mathrm{~A} / \mathrm{G}$ & 0.447 \\
\hline rs7217186 & $A L O X 15$ & 17 & $\mathrm{C} / \mathrm{T}$ & 0.472 \\
\hline rs4694075 & $A M B N$ & 4 & $\mathrm{C} / \mathrm{T}$ & 0.479 \\
\hline rs34538475 & $A M B N$ & 4 & $\mathrm{G} / \mathrm{T}$ & 0.187 \\
\hline rs17878486 & $A M E L X$ & $\mathrm{X}$ & $\mathrm{C} / \mathrm{T}$ & 0.111 \\
\hline rs946252 & $A M E L X$ & $\mathrm{X}$ & $\mathrm{A} / \mathrm{G}$ & 0.300 \\
\hline rs11362 & $D E F B 1$ & 8 & $\mathrm{~A} / \mathrm{G}$ & 0.405 \\
\hline rs1800972 & $D E F B 1$ & 8 & $\mathrm{C} / \mathrm{G}$ & 0.154 \\
\hline rs12640848 & ENAM & 4 & $\mathrm{~A} / \mathrm{G}$ & 0.357 \\
\hline rs3796704 & ENAM & 4 & $\mathrm{~A} / \mathrm{G}$ & 0.120 \\
\hline rs2235091 & KLK4 & 19 & $\mathrm{C} / \mathrm{T}$ & 0.340 \\
\hline rs198968 & KLK4 & 19 & $\mathrm{~A} / \mathrm{G}$ & 0.313 \\
\hline rs2269436 & $L T F$ & 3 & $\mathrm{~A} / \mathrm{G}$ & 0.103 \\
\hline rs743658 & $L T F$ & 3 & $\mathrm{~A} / \mathrm{G}$ & 0.103 \\
\hline rs4547741 & $L T F$ & 3 & $\mathrm{C} / \mathrm{T}$ & 0.059 \\
\hline rs 17078878 & $L T F$ & 3 & $\mathrm{~A} / \mathrm{C}$ & 0.146 \\
\hline rs1784418 & MMP20 & 11 & $\mathrm{~A} / \mathrm{G}$ & 0.407 \\
\hline rs5997096 & TFIP11 & 22 & $\mathrm{C} / \mathrm{T}$ & 0.468 \\
\hline rs134136 & TFIP11 & 22 & $\mathrm{C} / \mathrm{T}$ & 0.337 \\
\hline rs7526319 & TUFT1 & 1 & $\mathrm{C} / \mathrm{T}$ & 0.338 \\
\hline rs4970957 & TUFT1 & 1 & $\mathrm{~A} / \mathrm{G}$ & 0.240 \\
\hline rs3828054 & TUFT1 & 1 & $\mathrm{C} / \mathrm{T}$ & 0.105 \\
\hline rs3790506 & TUFT1 & 1 & $\mathrm{C} / \mathrm{T}$ & 0.248 \\
\hline rs 2337360 & TUFT1 & 1 & $\mathrm{~A} / \mathrm{G}$ & 0.250 \\
\hline
\end{tabular}

Calif., USA). Predesigned probes were supplied by Applied Biosystems (Foster City, Calif., USA). Markers were chosen based on a previous association with caries experience, allele frequency, position on the gene and linkage disequilibrium relationships to maximize information content.

\section{Statistical Analysis}

Data was subsequently processed and analyzed using the Epi Info 3.3.2 statistical software package (http://www.cdc.gov/ epiinfo). Student's t test was used to assess mean differences, and $\chi^{2}$ or Fisher's exact tests were used to find the difference in frequencies between caries-free children and children with caries experience. Logistic regression analysis of each genetic marker was performed. The environmental factors identified as possible modifiers for ECC experience were included as covariates during the multivariate analyses to detect gene-environment interactions. The established a was 5\%, and the Hardy-Weinberg equilibrium was evaluated by $\chi^{2}$ test with 1 degree of freedom within each marker.

\section{Results}

Of the 259 children included in this study, 123 (47.5\%) were caries free and 136 (52.5\%) were children with caries experience. The mean age was 4.6 years (standard de- 
viation, SD, 0.61). Caries-free children (4.14 years old, SD 0.9) were younger than children with caries experience ( 4.45 years old, SD $0.32, \mathrm{p}=0.0001)$. Among the affected children, the $\mathrm{dmft}$ varied from 2 to 19 and the mean $\mathrm{dmft}$ was 5.16 (SD 5.5). In this group, the $\mathrm{dmfs}$ varied from 2 to 62 and the mean dmfs was 10.44 (SD 13.17). All children with caries experience had a carious lesion in at least 1 posterior tooth, and almost all children had additional lesions in an anterior tooth (130; 95.6\%). Demographic data and environmental risk factors for ECC are summarized in table 2. Two environmental factors were associated with ECC in this population. Brushing a child's teeth for the first time after the window of infectivity (19-31 months of age [Caufield et al., 1993]) was a risk factor for ECC (odds ratio 1.33; 95\% confidence interval 0.67-2.65). The frequency of sugar and/or acidic drink consumption each day increased the risk for ECC almost 3 times.

The environmental factors for ECC identified and described above were included in the multivariate analyses in order to identify gene-environment interactions. The results of the univariate and multivariate analyses of the association of genotypes with ECC are presented in table 3. The genotype TT in ALOX15 (rs7217186) was a risk factor for ECC in the multivariate analysis. The genotype GG in ENAM (rs1264848) was a protective factor for ECC in the multivariate analysis. The genotypes AG and GG in KLK4 (rs198968) were associated as protective factors with ECC in the multivariate analysis. The genotype CT in LTF (rs4547741) was a protective factor for EEC in the univariate and in the multivariate analyses. Finally, the genotype GG in TUFT1 (rs3790506) was a protective factor for ECC in the univariate and in the multivariate analyses.

\section{Discussion}

Although it is well established that multiple factors contribute to an individual's risk for caries, not many studies evaluated the interactions between environmental factors and genetic factors. The genome-wide scan of caries experience in primary dentition [Shaffer et al., 2011] included children 3-12 years of age as well as an analysis of genetic associations based on having sufficient or deficient home fluoride exposure. However, no statistically significant associations were found despite some borderline suggestive results. To the best of our knowledge, this is the first work to look for interactions between genetic variants and environmental factors in ECC. It is not difficult to propose that genetic mechanisms that modulate the enamel development and the immune response are involved with ECC experience and are influenced by factors such as oral hygiene, diet and possibly other environmental factors.

It is important to emphasize that both of the groups analyzed here had a similar lifestyle and relied on the same health service. Among all self-reported environmental factors analyzed here, only the frequency of sugar and/or acid drink consumption and the time of first toothbrushing were associated with ECC. Also, more caries-free children were among the 2- and 3-year-olds. For this reason, these factors were included as covariates in the multivariate analysis. Multivariate analyses are useful to elucidate the interactions of environmental factors and genetic variants influencing a given trait [Leboyer et al., 1998].

We studied genes involved in enamel development [ameloblastin $(A M B N)$, amelogenin (AMELX), enamelin (ENAM), kallikrein 4 (KLK4), matrix metalloproteinase 20 (MMP20), tuftelin (TUFT1) and tuftelin-interacting protein 11 (TFIP11)] and genes related to the immune response of the host $[\beta$-defensin 1 (DEFB1) and lactoferrin $(L T F)]$. Arachidonate 15-lipoxygenase (ALOX15) was associated with bone mineralization [Vilella et al., 2009], and it is plausible that this gene is involved in the formation of the hard structures of teeth. This gene has also been related to inflammatory response [Kelavkar and Badr, 1999]. Based on the complex and multifactorial nature of caries, it was not surprising that we found associations between some of these genes and ECC.

Dental enamel is a highly mineralized tissue with $85 \%$ of its volume occupied by hydroxyapatite crystals. This structure is rigorously controlled in ameloblasts through the interaction of a number of organic matrix molecules such as ENAM, AMELX, AMBN, TUFT1 and TFIP11. ENAM is the largest protein in the enamel matrix during development and comprises approximately $5 \%$ of total enamel matrix protein [Pavlic et al., 2007]. In our results, the multivariate analyses demonstrated that the GG in ENAM (rs1264848) was protective for ECC. Our previous study also demonstrated the association of this gene with caries experience in Turkish children when the presence of Streptococcus mutans was modeled with the T allele of rs3796704 [Patir et al., 2008]. Another study of our group demonstrated that the mechanism through which ENAM is possibly involved with caries consists in contributing to an enamel surface more susceptible to demineralization [Shimizu et al., 2012]. 
Table 2. Demographic characteristics and environmental risk factors for ECC in the studied population

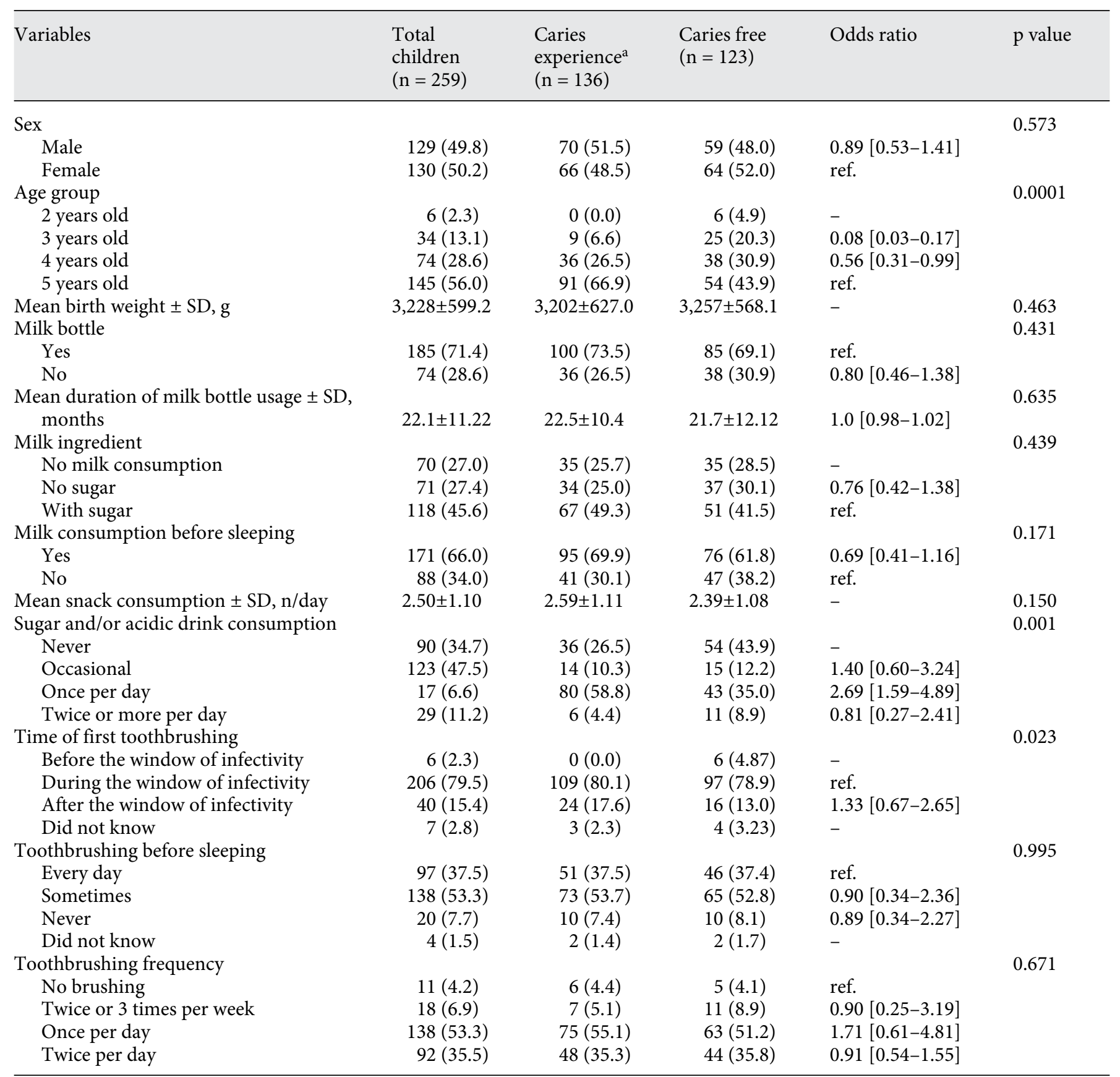

Figures in parentheses indicate percentages; figures in square brackets indicate $95 \%$ confidence intervals. p values $<0.05$ are considered statistically significant.

${ }^{a}$ Caries lesions were defined as a definite breakdown of enamel with or without an extension to dentin and visible white spot lesions due to demineralization of enamel.

ECC and Genetic Variants in Enamel Formation and Immune Response Genes 
Table 3. Univariate and multivariate analyses of the genotypes

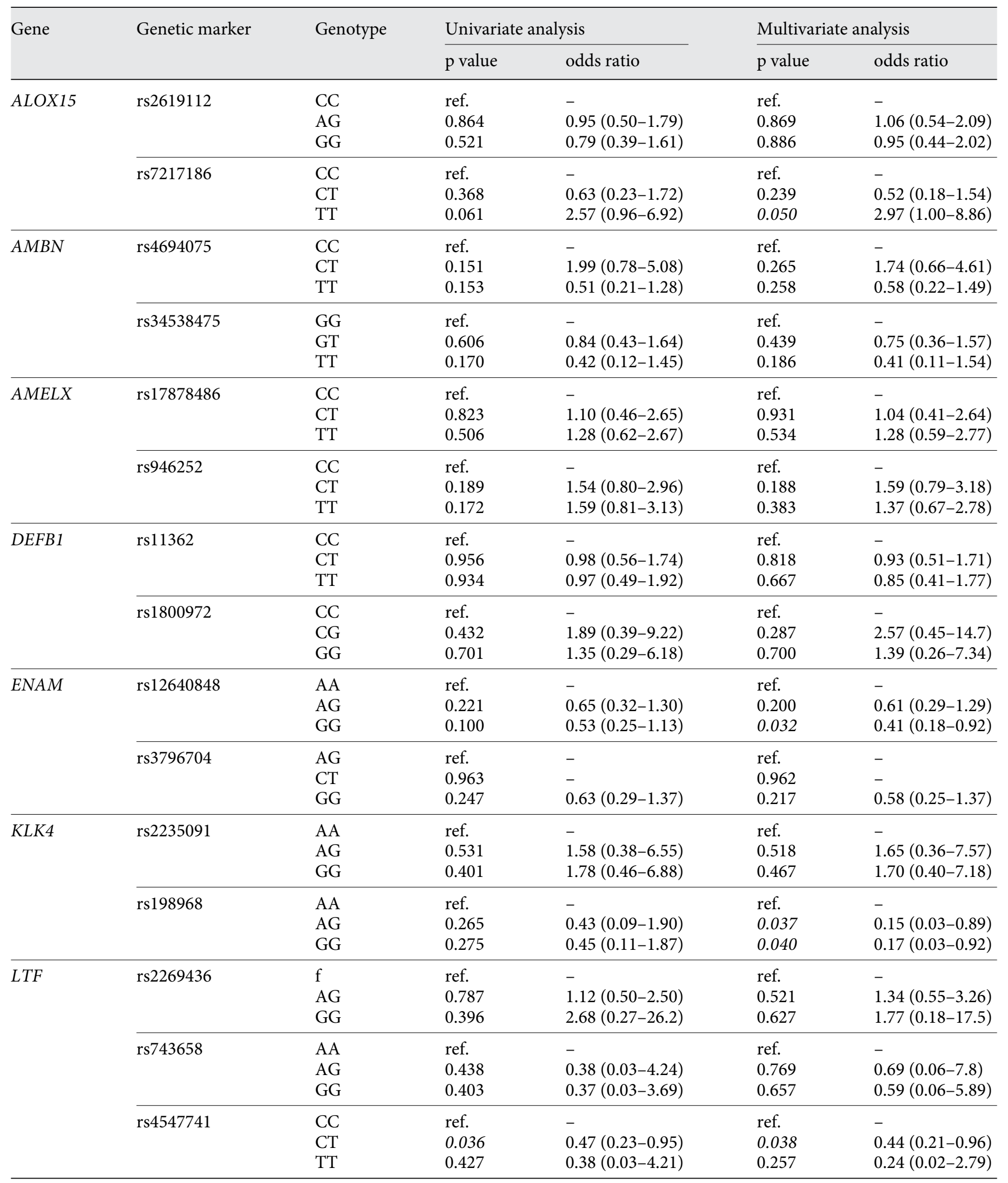


Table 3. (continued)

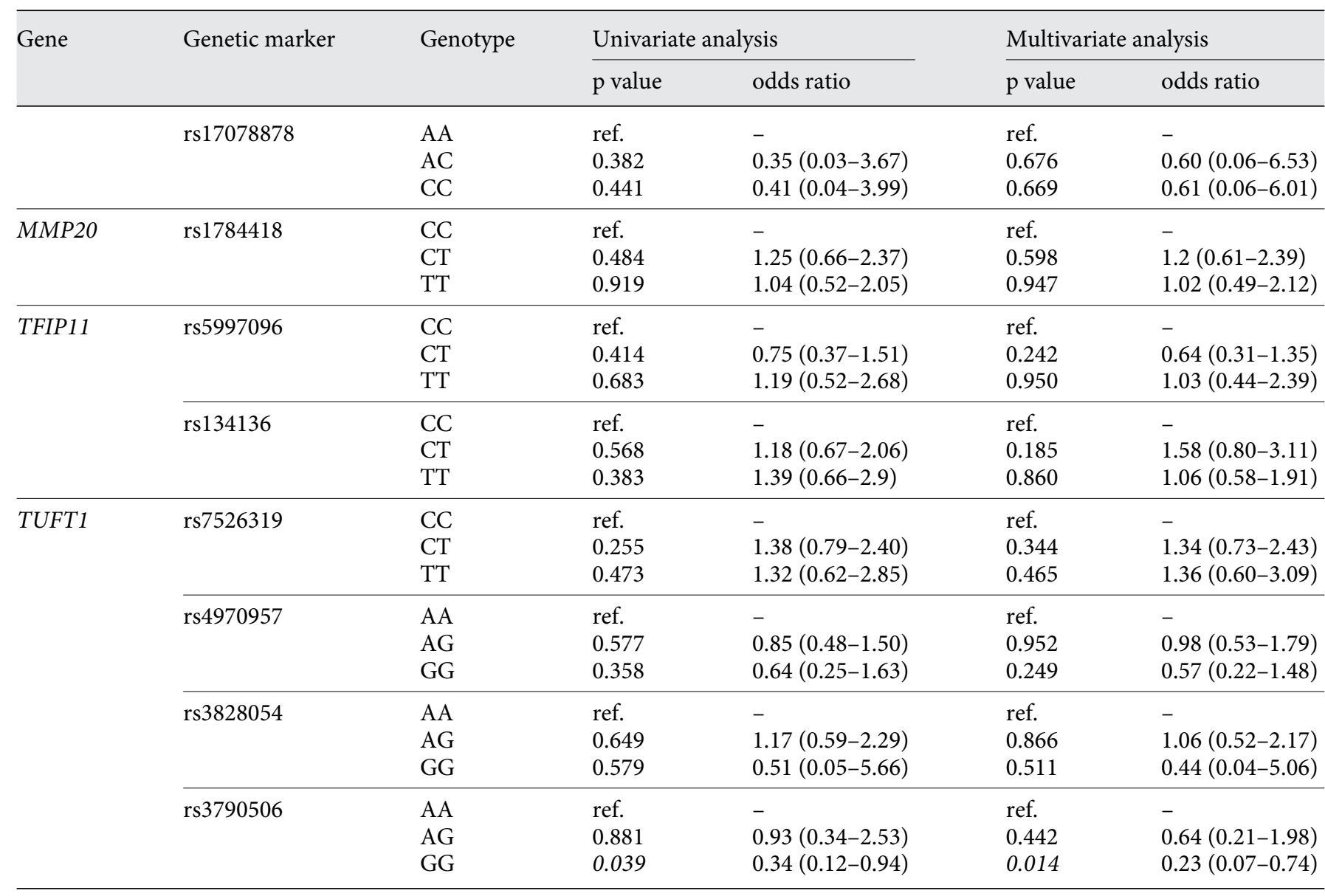

The analyses were adjusted for frequency, sugar and/or acid drink consumption and time of first toothbrushing. Figures in parentheses indicate $95 \%$ confidence intervals; italics indicate $\mathrm{p} \leq 0.05$. The markers rs 17878486 , rs 946252 , rs 3796704 , rs 2337360 were not in Hardy-Weinberg equilibrium and were not further tested.

We also found that the GG genotype in TUFT1 rs3790506 was protective for EEC in the univariate and multivariate analyses. Previous studies also found an association between this gene and caries experience in children [Slayton et al., 2005; Patir et al., 2008; Shimizu et al., 2012] and in adults [Deeley et al., 2008; Shimizu et al., 2012]. Slayton et al. [2005] suggested that two polymorphisms in TUFT1 interacted with the $S$. mutans present and explained $27 \%$ of the variability of caries experience in children from Iowa, USA. In Patir et al. [2008], the CT genotype of TUFT1 rs3790506 was overrepresented in cases with dmft scores $>5$. Shimizu et al. [2012] showed that the G allele of TUFT1 rs4970957 was overrepresented in populations both from Argentina and Brazil. In Guatemala, Deeley et al. [2008] showed that TUFT1 rs2337360 genotype distribution was different depending on whether individuals had DMFT scores of 2 or lower versus 3, 4, 5 or 6 and higher. Similarly to ENAM, the mechanism TUFT1 may predispose to caries by forming an enamel structure more susceptible to demineralization [Shimizu et al., 2012].

Mutations in MMP20 and KLK4 have been previously implicated in amelogenesis imperfecta [Ozdemir et al., 2005]. Our hypothesis is that common genetic variations of these genes may be involved in subclinical changes of the enamel and, as a consequence, may be involved in differences in caries experience. In the study presented here, the AG and GG genotypes in KLK4 (rs198968) are protective for ECC. We found no evidence of an association between EEC and MMP20. 
Regarding our findings related to the immune response of the host, we did not find an association with $D E F B 1$, a gene that we previously associated with caries in adults [Ozturk et al., 2010]. However, we found that a polymorphism in $L T F$ is associated with ECC. The fact that DEFB1 was not associated with ECC and LTF can be explained by the age of children affected by ECC and differences in microbiota of ECC. LTF is a glycoprotein that is present in various secretory fluids, including saliva, and has been previously associated with caries [Azevedo et al., 2010; Brancher et al., 2011]. It is one of the components of the immune system and has antimicrobial activity, particularly in human infants. $L T F$ plays an important role in fighting against Candida albicans [Viejo-Díaz et al., 2004] and, interestingly, C. albicans is an important component of dental biofilm associated with ECC [Yang et al., 2012]. Since C. albicans produces, and is also very tolerant of, acids, it has the potential to induce or exacerbate carious lesions [Klinke et al., 2011].

In spite of all that is known about preventing ECC, there are still children who appear to be more susceptible and some who are extremely resistant, regardless of the environmental risk factors to which they are exposed. In summary, our results suggest that genetic variation in genes involved in enamel formation and genes involved in immune response may contribute to ECC and that susceptibility results from gene-environment interactions.

\section{Acknowledgments}

The authors are indebted to the children and their parents who participated in this study. This study was supported in part by the NIH grant R01-DE18914.

\section{References}

American Academy of Pediatric Dentistry: Policy on early childhood caries (ECC): classifications, consequences, and preventive strategies. Pediatr Dent 2008;30:40-43.

-Azevedo LF, Pecharki GD, Brancher JA, Cordeiro CA Jr, Medeitors KG, Antunes AA, Arruda ES, Werneck RI, Azevedo LR, Mazur RF, Moysés ST, Faucz FR, Trevilatto PC: Analyis of the association between lactotransferrin (LTF) gene polymorphism and dental caries. J Appl Oral Sci 2010;18:166-170.

- Brancher JA, Pecharki GD, Doetzer AD, Medeitors KG, Cordeiro CA Jr, Sotomaior VS, Bauer P, Trevilatto PC: Analysis of polymorphisms in the lactotransferrin gene promoter and dental caries. Int J Dent 2011;2011:571726.

-Briseño-Ruiz J, Shimizu T, Deeley K, Dizak PM, Ruff TD, Faraco IM Jr, Poletta FA, Brancher JA, Pecharki GD, Küchler EC, Tannure PN, Lips A, Vieira TC, Patir A, Koruyucu M, Mereb JC, Resick JM, Brandon CA, Letra A, Silva RM, Cooper ME, Seymen F, Costa MC, Granjeiro JM, Trevilatto PC, Orioli IM, Castilla EE, Marazita ML, Vieira AR: Role of TRAV locus in low caries experience. Hum Genet 2013;132:1015-1025.

-Caufield PW, Cutter GR, Dasanayake AP: Initial acquisition of mutans streptococci by infants: evidence for a discrete window of infectivity. J Dent Res 1993;72:37-45.

Deeley K, Letra A, Rose EK, Brandon CA, Resick JM, Marazita ML, Vieira AR: Possible association of amelogenin to high caries experience in a Guatemalan-Mayan population. Caries Res 2008;42:8-13.

Drury TF, Horowitz AM, Ismail AI, Maertens MP, Rozier RG, Selwitz RH: Diagnosing and reporting early childhood caries for research purposes. A report of a workshop sponsored by the National Institute of Dental and Craniofacial Research, the Health Resources and Services Administration, and the Health Care Financing Administration. J Public Health Dent 1999;59:192-197.

- Ferreira SH, Béria JU, Kramer PF, Feldens EG, Feldens CA: Dental caries in 0- to 5-year-old Brazilian children: prevalence, severity, and associated factors. Int J Paediatr Dent 2007;17: 289-296.

Kelavkar UP, Badr KF: Effects of mutant p53 expression on human 15-lipoxygenase-promoter activity and murine 12/15-lipoxygenase gene expression: evidence that 15-lipoxygenase is a mutator gene. Proc Natl Acad Sci U S A 1999;96:4378-4383.

Klinke T, Guggenheim B, Klimm W, Thurnheer $\mathrm{T}$ : Dental caries in rats associated with Candida albicans. Caries Res 2011;45:100-106.

Leboyer M, Bellivier F, Nosten-Bertrand M, Jouvent $R$, Pauls $D$, Mallet J: Psychiatric genetics: search for phenotypes. Trends Neurosci 1998; 21:102-105.

Levy SM, Warren JJ, Broffitt B, Hillis SL, Kanellis MJ: Fluoride, beverages and dental caries in the primarydentition. Caries Res 2003;37:157-165.

Menghini G, Steiner M, Imfeld T: Early childhood caries - facts and prevention. Ther Umsch 2008;65:75-82.

Ozdemir D, Hart PS, Ryu OH, Choi SJ, OzdemirKaratas M, Firatli E, Piesco N, Hart TC: MMP20 active-site mutation in hypomaturation amelogenesis imperfecta. J Dent Res 2005;84:1031-1035.

Ozturk A, Famili P, Vieira AR: The antimicrobial peptide DEFB1 is associated with caries. J Dent Res 2010;89:631-636.
Patir A, Seymen F, Yildirim M, Deeley K, Cooper ME, Marazita ML, Vieira AR: Enamel formation genes are associated with high caries experience in Turkish children. Caries Res 2008; 42:394-400.

Pavlic A, Petelin M, Battelino T: Phenotype and enamel ultrastructure characteristics in patients with ENAM gene mutations g.1318513186insAG and 8344delG. Arch Oral Biol 2007;52:209-217.

Ranade K, Chang MS, Ting CT, Pei D, Hsiao CF, Olivier M, Pesich R, Hebert J, Chen YD, Dzau VJ, Curb D, Olshen R, Risch N, Cox DR, Botstein D: High-throughput genotyping with single nucleotide polymorphisms. Genome Res 2001;11:1262-1268.

-Shaffer JR, Wang X, Feingold E, Lee M, Begum F, Weeks DE, Cuenco KT, Barmada MM, Wendell SK, Crosslin DR, Laurie CC, Doheny KF, Pugh EW, Zhang Q, Feenstra B, Geller F, Boyd HA, Zhang H, Melbye M, Murray JC, Weyant RJ, Crout R, McNeil DW, Levy SM, Slayton RL, Willing MC, Broffitt B, Vieira AR, Marazita ML: Genome-wide association scan for childhood caries implicates novel genes. J Dent Res 2011;90:1457-1462.

Shimizu T, Ho B, Deeley K, Briseño-Ruiz J, Faraco IM Jr, Schupack BI, Brancher JA, Pecharki GD, Küchler EC, Tannure PN, Lips A, Vieira TC, Patir A, Yildirim M, Poletta FA, Mereb JC, Resick JM, Brandon CA, Orioli IM, Castilla EE, Marazita ML, Seymen F, Costa MC, Granjeiro JM, Trevilatto PC, Vieira AR: Enamel formation genes influence enamel microhardness before and after cariogenic challenge. PLoS One 2012;7: e45022. 
Shimizu T, Deeley K, Briseño-Ruiz J, Faraco IM Jr, Poletta FA, Brancher JA, Pecharki GD, Küchler EC, Tannure PN, Lips A, Vieira TC, Patir A, Yildirim M, Mereb JC, Resick JM, Brandon CA, Cooper ME, Seymen F, Costa MC, Granjeiro JM, Trevilatto PC, Orioli IM, Castilla EE, Marazita ML, Vireira AR: Finemapping of 5q12.1-13.3 unveils new genetic contributors to caries. Caries Res 2013;47:273283.

-Slayton RL, Cooper ME, Marazita ML: Tuftelin, mutans streptococci, and dental caries susceptibility. J Dent Res 2005;84:711-714.

Tannure PN, Küchler EC, Falagan-Lotsch P, Amorim LMF, Luiz RR, Costa MC, Vieira AR, Granjeiro JM: MMP13 polymorphism decreases risk for dental caries. Caries Res 2012a;46:401-407.
Tannure PN, Küchler EC, Lips A, Costa MC, Luiz RR, Granjeiro JM, Vieira AR: Genetic variation in MMP20 contributes to higher caries experience. J Dent 2012b;40:381-386.

Tannure PN, Küchler EC, Romanos HF, Vieira AR, Costa MC, Granjeiro JM: Caries experience in individuals with cleft lip and palate. Pediatr Dent 2012c;34:127-131.

Vieira AR, Marazita ML, McHenry TG: Genomewide scan finds suggestive caries loci. J Dent Res 2008;87:435-439.

Viejo-Díaz M, Andrés MT, Fierro JF: Modulation of in vitro fungicidal activity of human lactoferrin against Candida albicans by extracellular cation concentration and target cell metabolic activity. Antimicrob Agents Chemother 2004;48:1242-1248.
-Vilella AJ, Severin J, Ureta-Vidal A, Heng L, Durbin R, Birney E: EnsemblCompara GeneTrees: complete, duplication-aware phylogenetic trees in vertebrates. Genome Res 2009; 19:327-335.

Wang X, Shaffer JR, Zeng Z, Begum F, Vieira AR, Noel J, Anjomshoaa I, Cuenco KT, Lee M-K, Beck J, Boerwinkle E, Cornelis MC, Hu FB, Crosslin DR, Laurie CC, Nelson SC, Doheny KF, Pugh EW, Polk DE, Weyant RJ, Crout R, McNeil DW, Weeks DE, Feingold E, Marazita ML: Genome-wide association scan of dental caries in the permanent dentition. J Dent Res 2012;92:432-437.

-Yang XQ, Zhang Q, Lu LY, Yang R, Liu Y, Zou J: Genotypic distribution of Candida albicans in dental biofilm of Chinese children associated with severe early childhood caries. Arch Oral Biol 2012;57:1048-1053. 